\title{
BAUHAUS 100: SYMMETRIES AND PROPORTIONS IN MODERN ARCHITECTURAL COMPOSITION
}

The architects' community is now celebrating the first centenary of Bauhaus. The famous design school of post-World War I Germany combined crafts with the fine arts, heralding a new architectural paradigm for modern life. Based on pure geometry and functionalism, it relied upon a scientific approach to re-create the human environment, to liberate the same from historical allusions, and to redefine culture as a product of rational thinking. Bauhaus changed the structure of the education of applied arts, and placed architectural master planning at the hub of all major specializations. However, those specializations were each progressive actualizations of traditional crafts due to the needs of industrialized construction. Materials were processed and objects were fashioned accordingly in the Werkstatts of the old campus at the Staatliches Bauhaus in Weimar, then in the southern wing of the new school in Dessau. Light penetrating through the great curtain wall of the new building was an achievement that presaged the age of transparency.

The connection between matter and structural concept was a key attribute of the thinking of Bauhaus architects. Their education started with elemental theoretical and material studies, which then progressed to skilful knowledge in the design of building elements, furniture and articles of personal use. Experimental objects and sets first exhibited in the Haus am Horn Ausstellungs were effective attempts to change the ordinary lifestyle of early 20th-century families into a better way of living, to cut down the costs of construction, to free the space from useless complication, and to let in more light. Consequently, these efforts also contributed to the spread of prefabricated elements, and 
boosted mass production, causing a fracture between Bauhaus masters propagating and opposing it (i.e., the argument between Oskar Schlemmer and Johannes Itten).

Whatever modernity derived from Bauhaus, the complexity of its education was rooted in the artistic aspect of Gesamtkunstwerk, the ideal of the "comprehensive artwork" originally popularized in the context of the 19th-century German opera. Indeed, the modernist architectural school created its own theatre in both a literal and figurative sense. The former remained in small circles of self-designed eurhythmy, while the latter has changed the surface of our planet. The 'crystal cathedral' proclaimed by Walter Gropius is not part of our future anymore, but the vision behind the average metropolises of the advanced world. Mies van der Rohe and Philip Johnson's Seagram Building became the new archetype for modern skyscrapers - not because of its laconic functionality, but because of its composition and dramatized, sometimes incongruent, industrial style that spoke more genuinely to the public through its visible structural elements than any ornamental façade could.

Modernism to Bauhaus was initially a different concept and behaviour of living under the aegis of the old Europe, yet it became a broadly generalized architectural language in America's wide-open spaces. Philip Johnson referred to it as the International Style, and categorized its features in order to give a simple guide to the nouvelle design - ironically, he later altered his style to post-modernism. His guide, though, is an important source to us, since Johnson described one of the characteristics of modern composition as a genuine play between the adaptation and the violation of symmetry. If he was right, then either the early Bauhaus or late neo-modernist compositions share the same principles.

The commemorative architectural issue of Symmetry: Culture and Science welcomed papers with different approaches focusing on symmetries and proportions in modern architectural composition. We expected studies either on the semiotics of the "international" architectural language, its role and metamorphosis over time, or the structural, psychological, sociological effects of the modern use of symmetry in architecture. Studies considering the impact of modern composition on architectural education were also welcome. Historical studies about the Staatliches Bauhaus, its institution, work methods, communications and human network were employed to re- 
introduce symmetry in a different light. Contemporary critiques and re-formularizations of Bauhaus compositional principles were appreciated as well.

A speciality of our current issue is that most of our authors are from Hungary, which is unprecedented in Symmetry's history. The reason for this choice, beyond all randomness of the accepted papers, is that our community wants to commemorate the relatively great amount of Hungarian Bauhauslers, most notably Marcel Breuer, Alfréd Forbát, Farkas Molnár and László Moholy-Nagy, all of whom played key roles in the development of the Modern Movement throughout the world. In the appendix, we also would like to invite attention to the White City (Tel Aviv), where Bauhaus took root and thrived to such a degree that its architecture became an integral part of the landscape. I need to say special thanks to James Reese for his invaluable contribution to setting these insightful articles into English.

Vilmos Katona 